\title{
The uses of gold nanoparticles and Citrullus colocynthis L. nanoparticles against Giardia lamblia in vivo
}

\author{
Musafer H. Al-Ardi \\ Al-Qadisiya, Ministry of Education, Iraq
}

\section{A R T I C L E I N F O}

\section{Keywords:}

C. colocynthis

Giardia lamblia

Gold nanoparticles

In vivo

Hematological parameters

\begin{abstract}
A B S T R A C T
Background: The herbs have been used to prevent and treat many diseases, because of their safe and available. With unique properties of gold nanoparticles, and its accurate ability to deliver medicines, making it a suitable for chemotherapy.

Objective: Citrullus colocynthis and gold nanoparticles were used in the treatment of Giardia lamblia in vitro, but not in vivo.

Materials and methods: Experimental animals were divided into three groups, control non-treated group (sub divided into infected and non-infected), group B (treated and non-infected), and group C (infected and treated). All infected groups inoculated with $2 \times 10^{4}$ cysts and all treated groups received an aqueous extract of fruits and nanoparticles of $C$. colocynthis as well as gold nanoparticles Once as single and twice as combination therapy. Mean of cysts in the stool (from the third day of infection) and remaining trophozoites in the intestines (after the eighth day of treatment) were counted, compered the effect of single or combine agents use among infected (treated and non-treated) groups. Some hematological and chemical parameters in the non-infected (treated and non-treated) groups Were compared and the toxicity of that nanoparticles was estimated.

Results: The current study revealed that combination therapy is better than a single treatment, and that treatment with gold plus $C$. colocynthis nanoparticles is better than treatment with gold nanoparticles and native $C$. colocynthis. The study did not record significant effect of all compounds in hematological and chemical parameters, although it recorded variations in the levels and concentrations of these parameters.

Conclusion: Uses of $C$. colocynthis nanoparticles combined with gold nanoparticles has the Highest efficiency in Giardiasis treatment in vivo, but with an incomplete cure. Biological parameters may be considered in some safety when using this type of nanoparticle.
\end{abstract}

\section{Introduction}

Giardia lamblia is Giardia lamblia is globally widespread Protozoa parasite ${ }^{1}$, endemic in the small intestine in humans and mammalian(1) belong to Mastigophora. ${ }^{2}$ Children, pregnant women and peoples who have weak immunity are more infected from Others. It transmitted through contaminated water and food with cysts and causes diarrhea. ${ }^{3}$ Trophozoit lacks mitochondrial, endoplasmic reticulum, and Golgi apparatus, so it is an obligate parasite. Causes (due to toxins secreted) abdominal pain and intermittent constipation, fatigue, and weight loss (especially in children), may develop into the formation of gallstones and the appearance of jaundice). ${ }^{4}$

Since 1994, medicinal herbs have been certified as food and have been evaluated for safety before being distributed to the market or consumed). ${ }^{5}$ Leaves, stems, and seeds extracts have also been used in public medicine to treat many types of pathogenic microorganisms. ${ }^{6}$
C. colocynthis L. is Perennial creeping herbaceous plant. Its fruit (spongy pulp) contains Cucurbitales, which the active substance where it contains resinous substances and alkaloids with a laxative effect, the most important of which is the Elatyrene A and Elatyrisin B, also Contains pectin and soap, in addition to clicosides called calocynthidin Once be bait. ${ }^{7}$ (It has been used in the treatment of many conditions and pathological organisms, such as the treatment of diabetes) ${ }^{8}$, cancers $^{9},{ }^{10}$; and the efficiency of the aqueous and alcoholic extract of the plant was tested on different bacteria. ${ }^{11}$

The of antibiotics excessive use against different pathogens creates resistance against immunity, that leading to their ineffectiveness again, in addition to their impact on the health, So, the appropriate alternative is a nanoparticle antibiotic. ${ }^{12}$ The applications of nanomaterials and the uses of nanoscience in practical life is the other side of the coin that reflects the extent of scientific progress. It has created a new multidisciplinary view on the behavior of atoms and molecules on a tiny nifty

E-mail address: Mussafir78@yahoo.com. 
scale, this resulting in an unprecedented understanding of many aspects of the issue and a full knowledge of its basic characteristics never imagined before. ${ }^{13}$ Recently, much attention has been paid to the use of inorganic nanoparticles of nano-compounds to create materials with antimicrobial activity ${ }^{14}$, among these most promising nanoparticles are copper, zinc, titanium, magnesium, gold,and silver. ${ }^{13}$ Metallic nanoparticles, especially gold nanoparticles, have been known to have powerful toxic effects on a wide range of microorganisms. Preliminary studies have shown that cells and microbes are primarily affected by the low level of ion released from nanoparticles, for these broad-spectrum antimicrobial properties, nanoparticles have been used extensively for biomedical and other environmental disinfection applications for centuries. $^{15}$

\section{Materials and methods}

\subsection{Cysts collection}

a Samples were collected from the central laboratory in Al-Hamza General Hospital, examined by a light microscope with direct smear, Iodine dye was used, ten heavy cysts samples were selected for the next stage. ${ }^{16}$

b The great samples put in normal saline (0.9\%) then filtered. $3 \mathrm{ml}$ of faeces was layered on $3 \mathrm{ml}$ of $0.85 \mathrm{M}$ sucrose and centrifuged at 2000 for $10 \mathrm{~min}$ at $4 \mathrm{C}^{\circ}$. The cysts were aspirated at the sucrosewater interface and washed 3 times with normal saline. The cysts were added to $3 \mathrm{ml}$ of $0.85 \mathrm{M}$ and $0.4 \mathrm{M}$ sucrose. After centrifugation, the cysts concentrated at the $0.85-0.4 \mathrm{M}$ sucrose interface were collected and washed again. ${ }^{17}$ The purified cysts were suspended in normal saline and stored at $4 \mathrm{C}^{\circ}$ for a maximum of 3 days before use. $^{18}$

\subsection{Preparation of extracts and nanoparticles}

a Extraction of $C$. colocynthis:

The fruits of the plant Collected from Al-Shanafiyah district - Iraq, fruit were washed once with tap water and twice with distilled water, grinding the pulp of the fruit to form a powder, dissolved $5 \mathrm{~g}$ of powder in $50 \mathrm{ml}$ of distilled water stirring over a magnetic Heater for $(10 \mathrm{~min})$, the impurities were eliminated using two layers of gauze and blotting paper number one, discarded Centrifuge the extract and store at $-20 \mathrm{C}^{\circ} .^{19}$

b Preparation of $C$. colocynthis nanoparticles:

Prepared according to ${ }^{20}$, All materials have been brought from India MART Co. India.

c Preparation of gold nanoparticles:

Dissolved five mg of stock powder of gold nanoparticles (Nano shell co. USA) in $100 \mathrm{ml}$ distilled water to prepare the concentration $(0.05 \mathrm{mg} \backslash \mathrm{ml}){ }^{21}$

d. Preparation of green gold nanoparticles:

Preparation of nanoparticles was achieved according to ${ }^{21}$, where $90 \mathrm{ml}$ of $(0.05 \mathrm{mM})$ gold aqueous solution added to $10 \mathrm{ml}$ of (0.2 $\mathrm{mg} \backslash \mathrm{ml})$ C. colocynthis stock solutions with stirring, then kept all at room temperature for $24 \mathrm{~h}$. AuNPs in the AEs were first recognized by TEM analysis when the yellow color of gold changed to pink, then analyzed the shape and size of SNPs using TEM JEOL model JEM-2000EX (100 keV).

\subsection{Experimental animals}

50 Swiss Albino Mice (Mus Musculus) brought from the animal house - Veterinary Medicine Faculty - University of Al- Qadisiyah, were in good health and the average weight (20-26 g), divided into three main groups (5 mice) in each group as follows:

Group A: (control group) (10 mice) non treated was divided into two subgroups, a1 non-infected and a2 infected.
Group B: (15 mice) treated non-infected, divided into three subgroups b1 received $\mathrm{nCc}, \mathrm{b} 2$ received $\mathrm{nAu}$, and $\mathrm{b} 3$ received combination $\mathrm{nAu}+\mathrm{nCc}$.

Group C: (25 mouse) infected and treated as follows:c1 treatment with Cc extract, $\mathrm{C} 2$ treatment with $\mathrm{nCc}, \mathrm{c} 3$ treatment with $\mathrm{nAu}, \mathrm{c} 4$ treatment with $\mathrm{nAu}+\mathrm{Cc}$, and $\mathrm{c} 5$ treatment with $\mathrm{nAu}+\mathrm{nCc}$. All infected groups inoculated with $2 \times 104$ cysts of Giardia lamblia by nasogastric tube22, all treated animals received $(20 \mu \mathrm{g})$ of agents, as single or in combination for eight days. ${ }^{23}$

\subsection{Evaluations of parasite present}

A in stool:

Mice stools (groups C and a2) collected from the third to the eighth day, and examined with a light microscope using an iodine dye ${ }^{16}$, numbers of cysts from infected mice were counted by hematocytometer, synergy and reduction to treated group was evaluated as follows:

Reduction $=100-\left(\frac{\text { agent reduction }}{\text { control reduction }}\right) X 100$

Synergy $=\frac{\text { mean agent reduction }}{\text { combined therpy reduction }} \times 100$

The mean of cysts number for each group was compared with other groups to compare the efficacy of agents.

\section{B In intestine:}

On the eighth day, the infected animals were killed, the small intestine excreta was extracted, and the samples were examined with high power of the light microscope, using hematoxylin and eosin staining, ${ }^{24}$ numbers of trophozoit for all subgroups were counted, mean was evaluated to comparable between treated and non-treated, and among treated subgroups.

\subsection{Toxicity of nanoparticle}

A On the seventh day, blood (from groups B and a1) was drawn from the abdominal artery. Part of it was placed in EDTA tubes, red blood cell count (RBCs)and white blood cell count (WBCs) counted by Haemocytometer and the mean evaluated. ${ }^{25}$ Mean of Hemoglobin concentration $(\mathrm{Hb})$, corpuscular hemoglobin $(\mathrm{MCH})$, corpuscular volume (MCV), and corpuscular hemoglobin concentration $(\mathrm{MCHC})^{26}$, with kit from HyCell, Pejohesh-Co. Sweden.

B The other part of the blood is transferred to the centrifuge, isolate the serum for the analysis of albumin ${ }^{27}$, creatinine ${ }^{28}$, cholesterol ${ }^{29}$, random blood sugar. ${ }^{30}$ Using kit from HyCell, Pejohesh-Co, Sweden.

\subsection{Statistical Analysis}

Mean of cysts (excreted in 6 days) and remaining trophozoites (at eighth day) were calculated, a Synergy and Reduction according to Equation in 4a were estimated. means and SD of blood cells, haematological, and chemical parameters were calculated. The inter-group variation was measured by one-way analysis of variance (ANOVA) followed by Post Hoc LSD test at a significant value of $\mathrm{P}<0.01$ by statistical analysis Spss version $24 .{ }^{31}$

\section{Results}

With a Stool examination, a single treatment with fruits aqueous (Native $C$ ), and nano compounds (nCc, and $\mathrm{nAu}$ ) Showed moderate decrease of $G$. lamblia cysts, when recorded mean $(1.75 ; 1.16 ; 1.22)$ respectively, While the increase in the mean continued in the nontreated group(3.14). Native $C$ was the lowest effect with reduction 
Table 1

Numbers of cysts of parasite in stool samples of treated and non-treated infected mice.

\begin{tabular}{llll}
\hline Mice & Mean & Reduction\% & Synergy \\
\hline $\mathrm{CTRL}$. & $3.14 \mathrm{c}$ & & \\
$C c$ & $1.75 \mathrm{~b}$ & 44.3 & \\
$\mathrm{n} C c$ & $1.16 \mathrm{a}$ & 63.1 & \\
$\mathrm{nAu}$ & $1.22 \mathrm{a}$ & 61.2 & 62.7 \\
$\mathrm{nAu}+C c$ & $0.5 \mathrm{~d}$ & 84.1 & 67.4 \\
$\mathrm{nAu}+\mathrm{n} C c$ & $0.25 \mathrm{e}$ & 92.1 & \\
\hline
\end{tabular}

Cc: C. colocynthis; nCc: C. colocynthis nanoparticles; nAu: gold nanoparticles. Small different letters means significant.

(44.3\%) followed by nAu and nCc with $(61.2 \%, 63.1 \%)$ reduction respectively. Inter-group mean variation showed non-significant between $\mathrm{nCc}$ and $\mathrm{nAu}$, but the variation between nano compounds and Native $C$, and between treated and non-treated groups was significant(Table 1).

The combined treatment gave better results than single, and the combination between nanoparticles (nAU $+n C c)$ was better than the combination between nAu and native Cc. Table 1 reviewed the result with mean $(0.5 ; 0.25)$ and reduction $(84.1 \% ; 92.1 \%)$ respectively. The synergy between gold nanoparticles and $C$. colocynthis nanoparticles was the best (67.4).Fig. 1 schemed this increase. The difference between the two treated groups was significant, as well as, between each group in combination treatment and each other groups in a single treatment or with control(non-treated) group.

As same as with stool samples, a single treatment with native $\mathrm{C}, \mathrm{nCc}$, and nAu recorded good result in eliminating of trophozoites. Table 1 showed $(13.5,7.04,9.74)$ in mean and $(44.3 ; 61 ; 59.9)$ in the reduction for the three treatments respectively, this means nCc had Stronger effectiveness than $\mathrm{nAu}$ and native $\mathrm{C}$, followed by $\mathrm{nAu}$. The increasing in trophozoit mean of the non-treated group was continued(24.3). Despite the difference in the mean between ncc and nAu treated groups, stay non-significant, the difference between treated groups with nanocompounds from one side, and aqueous extract group and the untreated group (control) in other side was significant, also the difference between native $C$ and control groups was significant too (Table 2) (Fig. 1). showed some parameters.

The combined treatment with nano-compounds showed great results. When recorded reduction for Giardia trophozoites as $(93.2 \%$; $82.3 \%)$ in treatment with $(\mathrm{nAu}+\mathrm{nCc})$ and $(\mathrm{nAu}+\mathrm{Cc})$ respectively. Table 1 showed $(4.3 ; 1.7)$ as mean of Giardia trophozoites after treated with $(\mathrm{nAu}+\mathrm{cc})$ and $(\mathrm{nAu}+\mathrm{nCc})$ respectively, the synergy of combined compounds was (64.9) between $(\mathrm{nAu}+\mathrm{nCc})$ and (63.3) between

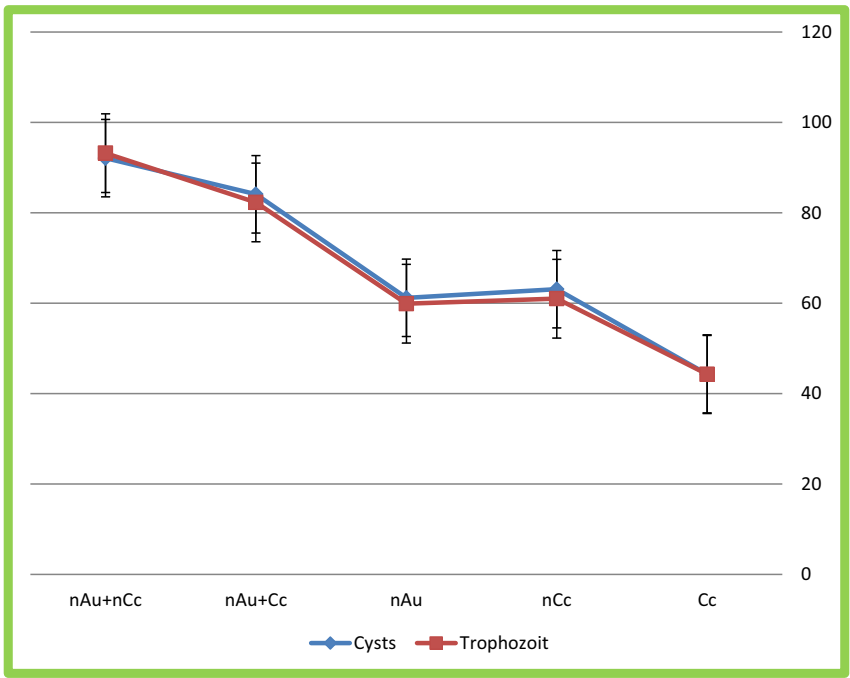

Fig. 1. Reduction of Giardia lamblia cyst and trophozoite in treated mice.
Table 2

Numbers of parasite trophozoites of in small intestine of treated and nontreated infected mice.

\begin{tabular}{llll}
\hline Mice & Mean & Reduction\% & Synergy \\
\hline $\mathrm{CTRL}$ & $24.3 \mathrm{c}$ & & \\
$C c$ & $13.5 \mathrm{~b}$ & 44.3 & \\
$\mathrm{n} C c$ & $7.04 \mathrm{a}$ & 61 & \\
$\mathrm{nAu}$ & $9.74 \mathrm{a}$ & 59.9 & 63.3 \\
$\mathrm{nAu}+C c$ & $4.3 \mathrm{~d}$ & 82.3 & 64.9 \\
$\mathrm{nAu}+\mathrm{nCc}$ & $1.7 \mathrm{e}$ & 93.2 & \\
\hline
\end{tabular}

abrAbbreviationsCc: C. colocynthis; nCc: C. colocynthis nanoparticles; nAu: gold nanoparticles.(Small different letters means significant).

(nAu $+\mathrm{Cc}$ ). From this result, we show that the combination of $(\mathrm{nAu}+\mathrm{nCc})$ was better than $(\mathrm{nAu}+\mathrm{Cc})$, and this difference was significant. In another hand, The variance between each group in the combined treatment with each group of a single treatment or with the control group was significant too.

The compounds contained in $C$. colocynthis can stimulate stem cells or activate the enzymes that participate or control the process of generation of blood cells. Therefore, some excessive cell generation and an increase in some of the associated parameters may occur, consistent with these reasons, the current study indicated a slight increase in these cells and parameters. Blood cells account mean and hematological parameters mean had major increasing in $(\mathrm{nAu}+\mathrm{nCc})$ treatment, while the treatment with $\mathrm{nCc}$ as single was the lowest. Inter-group mean variation showed non-significant. The mean and standard differentiation (SD) shown in Table 3.

Table 4 shows the mean and SD for some chemical parameters, it is clear from the reading of the below table a slight decrease in the maen of parameters cholesterol, creatinine, and random blood sugar, while the study recorded a slight increase in albumin among groups that treated with nano-compounds when compared with the control group. Albumin parameters recorded $(3.12 ; 3.26 ; 3.18 ; 3.44)$ as mean in control and $\mathrm{nCc}, \mathrm{nAu}$, and $\mathrm{nAu}+\mathrm{nCc}$ treated groups respectively, Despite this difference was non-significant. As well as, variation among treated and control groups was non-significant.

\section{Discussion}

C. colocynthis contained protein, separated amino acid, carbohydrate, phenolics, tannins, saponins, flavanoids, flavone, alkaloids, glucosides, anthranol, terpenoids, steroids, cardic glycoloids, saponarin, cucurbitacins, trace elements, and many other chemical groups. ${ }^{32}$ Has a regulating effect of insulin ${ }^{33}$ and decrease the blood sugar level, ${ }^{34}$ antitumors $^{35}$ and antioxidant effect ${ }^{36}$

Its leaves, seeds, and fruits possess high toxic effect, these inhibit the growth of pathogenic microbes and activate the immune reaction. ${ }^{32}$ The mechanism of its antimicrobial effect is by effect in a variety of weak enzymatic systems including enzymes which contribute to the synthesis of structural components or energy production, ${ }^{37}$ or presence of glycosides that can cause hydrolysis and release the toxic phenolex ${ }^{38}$

Several local medicinal herbs were used in the treatment of Giardiasis ${ }^{39} ;{ }^{40} ;{ }^{41}$ We used C. colocynthis and its nanoparticles as a treatment for Giardiasis in vivo for the first time, and showed good results somewhat matched with the last use of other herbal extracts against the same parasite.

The aqueous and alcoholic extract of $C$. colocynthis was used as an antipathogen. ${ }^{42},{ }^{43}$ used the extracts of leaves as antibacterial and antifungal in vitro. ${ }^{44}, 45$; observed vacuolisation in subsyncytial zone and parenchymatous cells, the acetabulum of treated parasite revealed damage, breakage, and vacuolisation in musculature of sucker of worms. ${ }^{46}$ proved highly effective for melon in killing leishmanias cells.

The current study showed moderate activity of gold nanoparticles against G. lamblia, this is consistent with different previous studies. ${ }^{47}$ 
Table 3

Hematological parameters in no infected - treatment groups.

\begin{tabular}{|c|c|c|c|c|}
\hline Hem.parameter & CTRL. & $\mathrm{n} C c$ & $\mathrm{nAU}$ & $\mathrm{nAU}+\mathrm{n} C c$ \\
\hline $\operatorname{RBCs}\left(10^{6} / \mathrm{u}\right) *$ & $8.40 \pm 1.22$ & $8.32 \pm 0.79$ & $8.57 \pm 1.26 \mathrm{a}$ & $8.56 \pm 1.4$ \\
\hline WBCs $\left(10^{3} / \mathrm{u}\right)^{*}$ & $8.04 \pm 0.78$ & $8.06 \pm 0.68$ & $8.08 \pm 0.759$ & $8.23 \pm 0.76$ \\
\hline $\mathrm{Hb}(\mathrm{g} / \mathrm{dI})^{*}$ & $13.0 \pm 1.16$ & $13.32 \pm 1.32$ & $13.30 \pm 1.01$ & $13.50 \pm 1.32$ \\
\hline $\operatorname{MCV}(\%)^{*}$ & $47.09 \pm 11.18$ & $46.39 \pm 10.83$ & $45.9 \pm 9.69$ & $45.9 \pm 9.88$ \\
\hline $\mathrm{MCH}(\mathrm{pg})^{*}$ & $17.47 \pm 1.71$ & $17.52 \pm 1.52$ & $17.52 \pm 1.61$ & $17.54 \pm 1.65$ \\
\hline $\operatorname{MCHC}(\mathrm{g} / \mathrm{dI})^{*}$ & $34.40 \pm 2.42$ & $33.22 \pm 1.35$ & $33.21 \pm 1.25$ & $33.55 \pm 1.48$ \\
\hline
\end{tabular}

*Non-significant.

Table 4

Chemical parameters in no infected - treatment groups.

\begin{tabular}{lllll}
\hline $\begin{array}{l}\text { Chem. } \\
\text { Parameter }\end{array}$ & CTRL. & $\mathrm{nCc}$ & $\mathrm{nAU}$ & $\mathrm{nAU}+\mathrm{nCc}$ \\
\hline Albumin* & $3.12 \pm 0.40$ & $3.26 \pm 0.45$ & $3.18 \pm 0.41$ & $3.44 \pm 0.54$ \\
CHO.* & $43.61 \pm 3.41$ & $42.51 \pm 5.91$ & $43.36 \pm 5.68$ & $43.34 \pm 6.15$ \\
CRE.* & $0.41 \pm 0.056$ & $0.39 \pm 0.049$ & $0.40 \pm 0.05$ & $0.39 \pm 0.044$ \\
RBs* $^{*}$ & $133.7 \pm 15.8$ & $130.5 \pm 17.02$ & $132.9 \pm 15.9$ & $130.3 \pm 18.3$ \\
\hline
\end{tabular}

CHO cholesterol, CRE creatinine, RBS random blood sugar.

*Non-significant.

confirmed the ability of nanoparticles to penetrate the cuticle and kill mosquito larvae. ${ }^{48}$ noted the toxic effect of gold nanoparticles on Schistosoma mansoni in mice. ${ }^{49}$ demonstrated the ability of AuNPs to kill the tachyzoite of Toxoplasma gondii. ${ }^{50}$ confirmed the effectiveness of gold nanoparticles from leaf extracts of Annona muricata in the elimination of bacteria and fungi species. ${ }^{51}$ went to say that AuNPs raise the immune system, thus facilitates the elimination of various parasites and their insect vectors, on the other hand, confirmed ${ }^{52}$ weak ability of AuNPs to treat leishmania major in vivo compared to AgNPs.

This study indicated a small increase in the number of red blood cells and other hematological parameters after the seventh day of administration. ${ }^{53}$ pointed out that $C$. colocynthis contains proteins, carbohydrates, and iron that Contribute to blood cell synthesis. ${ }^{54}$ Noted significant increase in lymphocytes and phagocytic cells in vitro when treated with C. colocynthis. ${ }^{55}$ traced the reason of increase of white blood cells in rabbits that treated with $C$. colocynthis to stimulate the immune system to produce antibodies And macrophage cells. ${ }^{56}$ confirmed that $C$. colocynthis stimulates the immature myeloid cells and prevents the inhibiting factors of bone marrow cell proliferation.

C. colocynthis stimulates the thyroid gland to increase the secretion of Tri-iodothyronine hormone, thereby increasing of the overall metabolism. ${ }^{5557}$ noted the ability of $C$. colocynthis to stimulate the production of high concentrations of important liver enzymes in metabolism, On the other hand, ${ }^{58}$ pointed the effect of $C$. colocynthis to decrease the concentration of cholesterol and fat in mice. ${ }^{59}$ added also a decrease of liver enzymes concentration, mechanism of the plant to induce consumption of sugar in surrounding tissues, inhibit the analysis of glycogen, or activate the conversion of excess sugar to glycogen ${ }^{60}$ or anaerobic glucose consumption and prevent its formation from noncarbohydrate compounds ${ }^{61}$

\section{Conclusions}

The uses of gold nanoparticles and nanoparticles or extraction of $C$. colocynthis was safe, combine therapy was better than single therapy when use herbal and gold nanoparticles in treatment have shown high efficacy in eliminating of cysts or trophozoits of G.lamblia.

\section{Suggestions}

Test the effectiveness effective of $C$. colocynthis and gold nanoparticles in combination with other compounds against the parasite, examine the toxic effect of nano compounds within tissues or on organ activity.

\section{Ethical considerations}

All animal were conducted under the protocols approved by the Veterinary Medical Faculty \Al- Qadisiyah University before the commencement of the study. Samples were collected from hospitalized patients who had been diagnosed by a physician.

\section{Knowledge}

Full thanks to supporting of Al-Hamza general hospital, Al-Diwaniya veterinary hospital, EMT unit in science faculty - Al-Kufa university.

\section{References}

1. Mahmud R, Yvonne ALL, Amir A. Medical ParasitologyA Textbook. Springer International Publishing; 2017:198.

2. Ryan U, Caccio SM. Zoonotic potential of Giardia. Int J Parasitol. 2013;43:943-956.

3. Raissi V, Zibaei M, Aliabadi PS, Baghi ZH, Etemadi S. Survey of giardiasis symptoms in patients referred to health care centers in zahedan, south-eastern Iran, 2017-2018. Int J Enteric Pathog. 2019;7(4):130-133.

4. Atyfi YZ. Vertinary Parasitology. Dar alqalam, Egypt; 2011:486.

5. Hassan SA, Kumar S, Dwivedi S, et al. Research and development in medicinal plants. JMAPS (J Med Aromat Plant Sci). 2000:22-23.

6. Oketchrabah HA, Dossaji SF, Brogger CS, et al. Antiprotozoal compound from Asparagus africanus. J Nat Prod. 1997;60(19)

7. Al - Saadi, Mohammed. The Secrets of Medicinal Plants and Drugs in Ancient and Modern Medicine. Amman, Jordan, DarYazuri: Arabic book; 2006:1.

8. AL-Chalabi NS. Study effects of Citrullus colocynthis seeds on blood glucose level in rats. Tikrit J Pure Sci. 2009;14(1) 18131662.

9. Al-Naemi HA. Study of cytotoxic effect of crude extracts of Bidens tripartita ,Panexinseng, Ceylon cinnamon and Citrullus colocynthis on mice mammary adenocarcinoma cell line.Ibn Al-Haitham. J. Pure Appl. Sci. 2011;24(2) 16094042.

10. Ahmed SA. Isolation some active materials in the iraqi fruits and seeds of Citrullus colocynthis L. and study of their effects on aqueous and alcoholic extracts of some pathological bactria and cancer cells type 120b. J. Univ. Anbar Pure Sci. 2013;7(2) 19918941.

11. Al-Janabi SJ, Abed OA, Durwish MJ. The study of antimicrobial activity of Citrullus colocynthis seeds. J. Biotechnol. Res. Center. 2012;6(1) 18151140.

12. Satyavani K, Ramanathan T, Gurudeeban S. Green synthesis of silver nanoparticles by using stem derived callus extract of bitter apple (Citrullus colocynthis). Digest J. Nanomater. Biostruct. 2011;6(3):1019-1024.

13. Jesline A, John NP, Narayanan PM, Vani C, Murugan S. Antimicrobial activity of zinc and titanium dioxide nanoparticles against biofilm-producing methicillin-resistant Staphylococcus aureus. Appl Nanosci. 2015;5(2):157-162.

14. Ladj R, Bitar A, Eissa M, et al. Individual inorganic nanoparticles: preparation, functionalization and in vitro biomedical diagnostic applications. J Mater Chem B 2013;1:1381.

15. Zeljka D, et al. Comparative in vivo evaluation of novel formulations based on alginate and silver nanoparticles for wound treatments. J Biomater Appl. 2018;32(9):1197-1211. https://doi.org/10.1177/0885328218759564 February 20, (2018) Research Article.

16. Burnett D, Crocker J. The Science of Laboratory Diagnosis. second ed. England: John Wiley \& Sons Ltd; 2005:240.

17. Abdel halim AS, Mohamed I, Ahmed MA, Amir BM. Antiparasitic activity of silver and copper oxide nanoparticles against Entamoeba histolytica and Cryptosporidium parvum cysts. J Egypt Soc Parasitol. 2015;45(3):593-602.

18. Uga S Uga S, Kimura D, Kimura K, Margon SS. Intestinal parasitic infections in Bekasi district, West Jova, Indonesia and acomparison of the infection rates determined by different techniques for faecal examination. Southeast Asian J. Trop. Med. Publ. Health. 2002;33:462-467.

19. Azizi S, Rosfarizan M, Mahnaz Ma S. Green microwave-assisted combustion synthesis of zinc oxide nanoparticles with Citrullus colocynthis (L.) schrad: characterization 
and biomedical applications. Molecules. 2017;22:301 10.3390.

20. Nam SH, Yeong HN, Ryang JJ, Baek IS, Park J-S. Curcuminloaded PLGA nanoparticles coating onto metal stent by EPD. Bull Kor Chem Soc. 2007;28(3):397-403.

21. Shawkey AM, Rabeh MA, Abdulall AK, Abdellatif AO. Green nanotechnology: anticancer activity of silver nanoparticles using Citrullus colocynthis aqueous extracts. Adv Life Sci Technol. 2013;13:53-59.

22. Youssef MYM, Eissa MM, Sadaka HAH, Rizk AM. Effect of ivermectin on combined intestinal protozoal infection (giardiasis and cryptosporidiosis). J Egypt Soc Parasitol. 1996;26(2):543-553.

23. Said DE, ElSamad LM, Gohar YM. Validity of silver, chitosan, and curcumin nanoparticles as anti-Giardia agents. Parasitol Res. 2012;111:545-554.

24. Schupp DG, Erlandsen SL. A new method to determine Giardia cysts viability: correlation of fluorescein diacetate and propidium iodide staining with animal infectivity. Appl Environ Microbiol. 1987;53:704-707.

25. Schalm OW, Jain NC, Carroll EJ. Veterinary Haematology. 3rd. philadephia: Lea and pebigers; 1975

26. Coles EH. Veterinary Clinical Pathology. fourth ed. Philadelphia: W.B. Saunders Company; 1986:486.

27. Doumas B, et al. Albumin standards and the measurement of serum albumin with bromcresol green. Clin Chem Acta. 1971;31(1):87-96. https://doi.org/10.1016/ 0009-8981(71)90365-2.

28. Murray R. Creatinine. 1984 In: Kaplaned. The C.V. St Louis.Toronto. Princeton: Mosby Co.; 1984:1261-1266 418.

29. Schettler G, Nüssel E. Colorimetric determination of Triglycerides and cholesterol Arb Med Soz Med Präv Med. 1975;10:25.

30. Trinder P. Determination of glucose in blood using glucose oxidase with an alternative oxygen acceptor. Ann Clin Biochem. 1969;6:24-27.

31. Suleiman OR. Statistical Analysis by SPSS Method. Cairo: The Anglo Egyptian Library; 2007:189.

32. Al-Snafi AE. Chemical constituents and pharmacological effects of Citrullus colocynthis - a review. IOSR J Pharm. 2016;6(3):57-67 March 2016.

33. Abdel-hassan IA, Abdel-barry JA, Tariq MS. The hypoglycaemic and anti hyperglycaemic effect of Citrullus colocynthis extract in normal and alloxan diabetic rabbits. $J$ Ethnopharmacol. 2000;71(1-2):325-330

34. Winkel-Shirley B. Biosynthesis of flavonoids and effects of stress. Curr Opin Plant Biol. 2002;5:218-223

35. Islam M, Azhar I, Mazhar F. Evaluation of antibacterial activity of bergeniaciliata. Pak J Pharm Sci. 2002;15(1):35-42.

36. Jayaraman R, Christina AJM. Evaluation of Citrullus colocynthis fruits on in vitro antioxidant activity and in vivo DEN/PB induced hepatotoxicity. Int J Appl Res Nat Products. 2013;6(1):1-9.

37. Conner DE, Beuchat L. Sensitivity of heat stressed yeasts to essential oils of plants. Appl Environ Microbial. 1984;47(2):229-233 PMC239649.

38. Aboaba O, et al. Antimicrobial activities of some Nigerian spices on some pathogens. Agric. Biol. J. N. Am. 2011;2(8):1187-1193.

39. Al-kaissi IN. The effect of Aqueous some plants Extract on Giardia lamblia in vitro.AlAnbar. J Vet Sci. 2010;3(2).

40. Ali JK, Swadi HA, Alewi HH. Experimental infection of pigeon birds with Giardia lamblia parasite isolated from human and treatment of infected birds with ginger extract. J Kerbala Univ. 2014;12(2).

41. AL-Khfaji MSA. Antigiardial activity of garlic (allium sativum) on white mice. $J$ Babylon Univ/Pure Appl Sci. 2017;25(3):2017.

42. Shyamala SG, Priyavardhini S, Vasantha K, Umadevi M. Ntibacterial activity on
Citrullus colocynthis Leaf extract. Ancient Sci Life. 2009;29(No.1):12-13 2009.

43. Gurudeeban S, Rajamanickam E, Ramanathan T, Satyavani K. Antimicrobial activity of Citrullus colocynthis in gulf of mannar. Int J Curr Res. 2010;2 078-081.

44. Swarnakar G, Kumaw A. In vitro anthelmintic effect of Citrullus colocynthis on tegument of amphistome Orthocoelium scoliocoelium (Trematoda: digenea). Int J Curr Microbiol Appl Sci. 2014;3(6):571-582.

45. Zaid KA, EL- Wakil H, EL-Hussein A, Jomma S, Shohayeb M. Evaluation of the molluscicidal activity of Punica granatum, Calotropis procera, Solanum incanum and Citrullus colocynthis against Biomphalaria arabica. World Appl Sci J. 2013;26(7):873-879.

46. Baloch N, Nabi S, Kakar AM, Wajid Z, AL-Kahraman. In vitro antileishmanial, antitumor, cytotoxic activities and phytochemical analysis of Citrullus colocynthis fruit extract and its fractions. Int J Med Aromatic Plants. 2013;3(1):78-84.

47. Murugan K, Benelli G, Panneerselvam C, et al. Cymbopogon citratus-synthesized gold nanoparticles boost the predation efficiency of copepod Mesocyclops aspericornis against malaria and dengue mosquitoes. Exp Parasitol. 2015;153:129-138.

48. Dkhil MA, Khalil MF, Bauomy AA, Diab MS, Al-Qura S. Original ArticleEfficacy of gold nanoparticles against nephrotoxicity induced by Schistosoma mansoni infection in mice. Biomed Environ Sci. 2016;29(11):773-781.

49. Vazini H, Esboei BR. The investigation of nanoparticles of gold's fatality effect on Toxoplasma gondii parasite in an in vitro study. J Antimicrob Agents. 2018;4:172. https://doi.org/10.4172/2472-1212.1000172.

50. Folorunso A, Akintelu S, Oyebamiji AK, et al. Biosynthesis, characterization and antimicrobial activity of gold nanoparticles from leaf extracts of Annona muricata. $J$ Nanostruct Chem. 2019;9(2):111-117.

51. Giovanni B. Gold nanoparticles - against parasites and insect vectors. Acta Trop. 2018;178:73-80 2018.

52. Lourdes CSL, lucas MB, Thayllan TB, et al. Silver and gold nanoparticles from tannic acid: synthesis, characterization and evaluation of anti leishmanial and cytotoxic activities. An Acad Bras Ciências. 2018;90(3):2679-2689 2018.

53. Wannang NN, Jimam NS, Omale S, Dapar MLP, Gyang SS, Aguiyi JS. Effects of Cucumis metuliferus (cucurbitaceae) fruits on enzymes and haematological parameters in albino rats. Afr J Biotechnol. 2007;6(No.22) 2515 - 2518.

54. Abbas AH. The effect of aqueous extract of Citrullius colocynthis seeds on cellular immunity. Baghdad Sci J. 2012;9(4).

55. Al-Dujaily SS, Manwar F, Ibrahim SH. Study of some physiological aspects in mature male rabbits after oral administration of Citrullus colocynthis. Iraqi $J$ Vet Med. 2012;36(2):209-216.

56. Shokrzadeh M, Chabra A, Naghshvar F, Ahmadi A. The mitigating effect of Citrullus colocynthis (L.) fruit extract against genotoxicity induced by cyclophosphamide in mice bone marrow cells. Sci World J. 2013;2013:8 Article ID 980480.

57. Al-Ghaithi F, El-Ridi MR, Adeghate E, Amiri MH. Biochemical effects of Citrullus colocynthis in normal and diabetic rats. Mol Cell Biochem. 2004;261(1-2):143-149.

58. Zamani M, Rahimi AO, Mahdavi R, et al. Assessment of anti hyperlipidemic effect of citrullus colocynthis. Braz J Pharmacogn. 2007;17(4):492-496.

59. Alabadi UA, Al-Ali Z. Effect of hot aqueous extract of Citrullus colocynthis L. Fruit on some biochemical and haemato-logical parameters in alloxan-induced diabetic rats. AlKufa Bio Sci J. 2010;2(2):1-9.

60. Matti MG. Some biochemical effects of neem seed oil on normal and alloxan induced diabetic mice. J Edu Sci. 2001;50:55-61 2001.

61. Kato A, Miura T. Hypoglycemic activity of Polyganati rhizoma in normal and diabetic mice. Biol Pharm Bull. 1993;16:1118-1120 1993. 